\title{
МИСТЕЦТВОЗНАВЧИЙ ПОШУК
}

удк: 7.071:666.1.037.3

$\begin{array}{ll}\text { Остап Іванишин } & \text { викладач кафедри художнього скла Львівської } \\ \text { національної академії мистецтв, аспірант } \\ \text { https://orcid.org/0000-0002-8304-0176 }\end{array}$

\section{Експеримент у творчості Клауса Мойє}

\begin{abstract}
Анотація. У статті висвітлено внесок творчої та освітньої діяльності відомого австралійського художника німецького походження Клауса Мойє у світову спадщину декоративного мистецтва у сфері художнього скла. Розкрито його інноваційний підхід до роботи з матеріалом. Досліджено роль митця в розвитку міжнародного руху студійного скла. 3'ясовано наслідки вдосконалення технології на перспективи розвитку техніки спікання скла в студійних умовах і впровадження іï в навчальні програми. Проведено короткий огляд основних публікацій і досліджень творчості митця та охарактеризовано його творчість упродовж чотирьох десятиліть. Виявлено результати співпраці з виробником спеціалізованих матеріалів. Здійснено короткий огляд ретроспективної виставки.
\end{abstract}

Ключові слова: творчість Клауса Мойє, міжнародний рух студійного скла, термоформаж, живопис у склі, реновація.

Постановка проблеми. Виникнення міжнародного руху 1 студійного скла на початку 60-х рр. ХХ ст. зумовило появу нових прізвищ у переліку видатних діячів культури та мистецтва. Одним з таких корифеїв був Клаус Мойє (1936-2016) австралійський художник німецького походження, що стояв біля витоків студійного руху та розвинув новий підхід у роботі зі склом. Його творчість є предметом досліджень багатьох зарубіжних критиків і мистецтвознавців у численних статтях, есе, інтерв'ю, каталогах і монографіях. Та, на жаль, його прізвище майже не згадується у вітчизняних дослідженнях, попри загострену увагу фахівців і студентів до техніки термоформажу та спікання скла, яку К. Мойє розвинув до високого рівня 
досконалості. Потреба висвітлити яскравий зразок світового рівня в царині художнього скла випливає з актуальності запитів молодих фахівців у пошуку методів реалізації творчого задуму із залученням новітніх технологій та ефектних медіумів. У сучасному українському декоративному мистецтві термоформаж як метод набирає все більш чітких обрисів серед доступних виражальних засобів.

Мета дослідження - визначити місце термоформажу в контексті явища міжнародного руху студійного скла, з'ясувати його відповідність основним принципам руху і вплив творчості К. Мойє на його розвиток, зокрема, через освітній процес; прослідкувати процес реновації техніки термічної обробки скла через творчий експеримент на прикладі доробку К. Мойє.

Аналіз досліджень і публікацій. Серед найбільш розповсюджених джерел інформації про К. Мойє, поки що залишаються інтерв'ю для спеціалізованих періодичних видань, таких як «Глас» (Glass), який видає щоквартально відомий американський мистецький центр «Урбан глас» (Urban Glass) у Нью-Йорку. Журнал «Глас» покликаний висвітлювати огляд і критику найважливіших творів мистецтва у склі протягом 35-ти років. Розширене інтерв’ю та публікації знаходимо в каталозі міжнародного бієнале щорічної конференції Міжнародної спілки художників скла (Glass Art Society), яка удостоїла К. Мойє нагородою «За життєві досягнення» в області студійного скла. Доволі об'ємний каталог видав австралійський куратор Меган Боттарі 2007 р., присвячений життю та творчості засновника сучасного термоформажу, що відслідковує його новаторську діяльність на трьох континентах упродовж 40-ка років. Альбом виданий з нагоди відкриття ретроспективної виставки в Сіднеї, що надалі була представлена в США і фіксує епізоди, що згадували різні художники, куратори, дилери та колекціонери. Ще одним змістовним джерелом $\epsilon$ альбом, який видав Портландський художній музей (США) 2008 р. $з$ нагоди виставки К. Мойє у музеї. Містить критику та есе від Брюса Гюнтера (організатора виставки, головного куратора музею), Дена Кляйна, Теда Сойєра. Нола Андерсон, провідний австралійський мистецтвознавець, дослідник, понад 15 років працює в галузі сучасного мистецтва, має великий досвід в дослідженні та кураторстві у спеціалізованій сфері художнього скла Австралії, працює над монографією, присвяченою творчості 


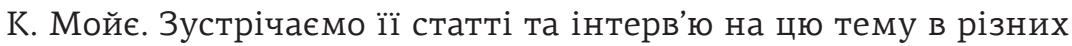
періодичних виданнях і на електронних ресурсах.

Виклад основного матеріалу. Митець з'явився у середовищі, яке характеризується потягом до авторського експерименту, відмовою від посередництва великих скляних підприємств і максимальним залученням автора до виконання у матеріалі. Процес, який сьогодні має назву «рух студійного скла» (Studio glass movement), виник у Америці на початку 60-х років XX ст. і поступово охопив інші континенти. Відправною точкою розвитку руху вважають семінари з гутного скла, які проводив, відомий і міжнародно визнаний художник Гарві Літтлтон - професор Університету Вісконсина в Медисоні, кераміст за фахом - у майстерні Художнього музею в Толедо. Метою семінарів було представити художникам використання гарячого скла як матеріалу для сучасного мистецтва [6]. Характерними особливостями руху були: самостійне виконання власного творчого задуму і повна взаємодія з матеріалом, унікальність творів; обмін досвідом на міжнародному рівні.

Специфіка роботи К. Мойє, усе ж, дещо відрізнялася від теоpiї, яка панувала на етапі становлення студійного руху: відома фраза його засновника Г. Літтлтона «Техніка - нічого не варта» (мається на увазі важливість творчого задуму понад технологією) [13, с. 51] - не відповідала тим прийомам, якими користувався К. Мойє. Техніка термоформажу передбачає серйозну підготовку «холодного» матеріалу, перш ніж заготовка потрапить до печі. Крім того, вже спечені заготовки також піддавалися «холодній» обробці - шліфуванню, розпилюванню тощо. Тож, бачимо, що без відповідної майстерності неможливо дсягти успіху в даній техніці. Сам автор так говорить про важливість володіння технікою: «Якщо ви освоїли ремесло, ви можете звільнитися від обмежень матеріалу. Ваша творча думка може працювати незалежно від опору, який створює матеріал» [3, с. 50]. На відміну від гутної техніки, яка вимагає більших потужностей і серйозної технологічної підготовки, термоформаж не потребує великого обладнання та багато площі. Йому притаманні автономність і камерність - одні з основних критеріїв студійного скла.

Техніка спікання скла була відома кілька тисяч років тому в культурі Межиріччя, проте була забута й витіснена більш практичною та економічно виправданою гутною технікою, що 
поширилась у Давньому Римі та Александрії. У Франції в кінці XIX - на початку XX ст. ця техніка отримала своє відродження. 3 початком індустріальної революції та появи музеїв зростала цікавість до давніх технік і пошук нових виражальних засобів. Найбільш яскраво термічне формування скла у печах проявилось тоді у знаменитих представників стилю сецесії - Р. Лялік, А. Кро, Г. Арш-Руссо, А. Вальтер, Ф. Декоршемон, Е. Галле та ін. [7, с. 10-11]. Вони освоїли досконало "раte de verre»- техніку «втраченого воску», що стала основою їх трактування матеріалу. Суть техніки полягає у протіканні розтопленого подрібненого скла чи скляного порошку в попередньо підготовлену форму. Прийоми К. Мойє зумовлені матеріалом, який він застосовує, - листове кольорове скло, нарізане смугами та складене в різнобарвну мозаїку з напівпрозорими та забарвленими накладами. Завдяки термічній обробці, «сухі» графічні площини набувають живописних рис із характерною грою світла й кольору, оптичних ефектів скла. Це були роботи нового типу. Одна з принципових відмінностей термоформажу полягає у використанні фабрично підготовленого матеріалу, в якому різні види скла мають однаковий коефіцієнт термічного розширення. Це стало можливим після історичної зустрічі К. Мойє з представниками фабрики вітражного скла Булсай (Bullseye Glass co.) 1981-го. Цій зустрічі передували роки експериментів, невдач і випробувань.

Клаус Мойє народився 1936 р. у Гамбурзі, Німеччина. Як фахівець почав формуватися в юному віці у стінах родинної майстерні з розкрою та обробки скла. Здобув кваліфікацію у фахових школах у місті Райнбах і Гадамар (Німеччина), де йому пощастило зустріти викладачів з Богемії, які були запрошені там працювати після Другої світової війни. Вони були бездоганними ремісниками та знали все про природу скла. Там він збагнув, що хоче мати свою власну майстерню. I вже на початку 1960-х, разом зі своєю першою дружиною Ізгарт, вони відкрили власну студію. На початках К. Мойє працював у техніці вітражу як виконавець і реставратор. Співпрацюючи з архітекторами, він познайомився з випускниками школи Баухауз. Це мало значний вплив на формування його ставлення до матеріалу. Клаусові Мойє імпонували принципи поєднання технології та образотворчості, що стало основою його подальшого творчого шляху та викладацької діяльності. На початку 1970-х у руки 
майстра потрапили скляні заготовки у вигляді склодроту сульфідно-цинкового легкоплавкого скла, що використовувалося для виготовлення гудзиків і біжутерії. Із цього моменту почалась епоха великих експериментів. Цікавість змушувала Клауса використати матеріал у таких умовах, у яких ніхто раніше його не застосовував. Те саме стосується й інструментів - майстер власноруч застосовував прецезійний індустріальний абразивний інструмент, що раніше не було прийнятним у студійних умовах. На його думку, при роботі з термоформажем митець повинен працювати з точним інструментом, щоби досягнути належного результату [8, с. 49]. У перших роботах К. Мойє, виконаних 3 легкоплавкого скла, переважає локальна колористична гама, не обтяжена складною текстурою рисунку. Традиційний формат твору, притаманний цьому періоду, - неглибокі чаші овальної або круглої форми. Тим не менше, уже на цьому етапі вони привернули увагу колекціонерів. Так, 1976-го одна з його чаш була відібрана до колекції Музею мистецтв і ремесел у Гамбургу. Це стало хорошим стимулом для продовження свого дослідження в техніці спікання. На той час К. Мойє погано орієнтувався в тому, як працювали у Давньому Римі чи, скажімо, в Італії тисячі років тому, також він не дуже знався на режимах відпалу та сумісності різних видів скла [8, с. 49]. Освоєння нової техніки зайняло роки. Зрештою, новий підхід, який він запровадив, дозволяє говорити про нього як реноватора - Клаус Мойє, сам цього не підозрюючи, вивів на новий рівень розвитку мистецтво скла. Завдяки термоформажу він надає цілком нового звучання традиційній техніці, ставить під сумнів матеріал і створює нове тлумачення та нові очікування від скла [12, с. 46]. Як сказав Др. Браян Кенеді, директор Національної австралійської галереї, «Мойє встановив міжнародний орієнтир новаторства та застосування скла, що виразно пояснюється його високо розвинутим відчуттям кольору, форми, міри та пропорції» [12, с. 46].

Поруч зі своєю майстернею, на околицях Гамбурга, на початку 1970-х К. Мойє відкриває галерею. Вона стала важливим приватним центром, де художники скла могли виставлятися та обмінюватися досвідом. У такий спосіб К. Мойє увійшов до середовища однодумців, у яких була одна мета - розвивати студійне скло. 1976 року К. Мойє познайомився з одним із найвпливовіших співзасновників руху студійного скла в Америці - Дейлом Чи- 
хулі. Разом з однодумцями Чихулі створив школу скла Пілчак у штаті Вашингтон, на східному узбережжі Тихого океану. Школа несла та розповсюджувала ідеї «руху» через навчальний процес із залученням всесвітньо визнаних майстрів гутної справи та інших технік обробки скла. Філософія освіти школи Пілчака походить з оригінальної ідеї Д. Чихулі «художників, які навчають художників». I, після майже сорока років, ця концепція все ще зберігається [5]. Тут викладали видатні постаті світової слави - Данте Маріоні, Станіслав Лібенський, Ярослава Брихтова, Анна Вулф, Ліно Тайліап'єтра та ін. 1979 року Д. Чихулі запросив К. Мойє викладати в Пілчак. Там він усвідомив, що його техніка не справляла такого враження, як динамічна гута, тому йому важко було завоювати прихильність студентів. Крім того, там бракувало відповідного скла, контрольованих печей та інструментів для шліфування [3, с. 50]. Однак атмосфера, яка панувала там на той час, залишила глибокий слід у формуванні його підходів до роботи зі склом та у викладацькій діяльності надалі. Це була атмосфера вільної, незаангажованої творчості, що грунтувалася на принципах експерименту та обміну досвідом, що прямо суперечила консервативним європейським, чітко окресленим естетичним умовностям. Почуття свободи, яке здобув К. Мойє у штатах, він переніс із собою назад, до Німеччини. Це відразу позначилося на його наступних творах - роботи стали більшими, бозбавленими ознак утилітарності, яскравішими...

Ще однією важливою подіє під час його поїздок до Америки було знайомство із представниками фабрики вітражного скла «Булсай» (Bullseye Glass co.), штат Орегон. Вони звернули увагу на його експерименти та труднощі, які виникали через несумісність скла. Ден Шворер, співзасновник підприємства, запропонував виготовити спеціальне скло для його потреб. I вже через два роки К. Мойє отримав першу експериментальну партію скла. Це був першокласний матеріал принципово нового типу з багатою колористикою. У цій співпраці між наукою і мистецтвом Мойє і Булсай значно розширили можливості скл, як медіума. Це стало сильним поштовхом у творчості К. Мойє - його роботи вибухнули яскравими барвами абстрактної мозаїки, яка не нагадувала попереднього і стала наріжним каменем для майбутньої практики. У свою чергу, компанія «Булсай» запровадила проект підтримки митців, що працюють у склі, зокрема в техніці термофор мажу, 
та ініціювала численні виставки. Цей період відзначився ще однією знаковою подією, що мала глибокий вплив на життя та творчість К. Мойє. На початку 1980-х митець проводив короткі курси в Європі та Америці, коли 1982-го прийшла пропозиція 3 Австралії. Удо Зельбах, директор Національного австралійського університету, запропонував К. Мойє створити та очолити відділ скла в їхній філії - Художній школі в місті Канберра. Це була чудова нагода створити навчальну студію за власним проектом, використовуючи весь здобутий досвід. Йому вдалося впровадити всесвітньо визнану освітню програму. Його спосіб навчання був поєднанням методів Баухауз із широким спектром традиційної та сучасної філософії навчання [11; 12]. Відкинувши «культ особистості», він, у першу чергу, навчав розумінню матеріалу та обміну досвідом з іншими. Практичний підхід виявився «життєдайним» в умовах академічного середовища. Завдяки цьому К. Мойє зміг вийти за рамки, якими академія так часто обмежувала знання замість того, щоби створити живий дискурс, у якому студенти та викладачі могли 6 спільно мислити та працювати.

Клаус Мойє абсолютно не прагнув клонувати собі подібних. Його завданням було виділити та розвинути індивідуальні риси кожного студента. Як згадує один з його перших студентів, Річард Вайтлі, «Найбільш надихаючим уроком завжди було спостереження за тим, як працює К. Мойє. Він створив сприятливу атмосферу обміну» [12]. Митець виховав наступні покоління, їх імена яскраво прозвучали на міжнародній арені сучасного мистецтва завдяки індивідуальній манері з тою ж відданістю матеріалу, що й у їхнього вчителя, водночас, виробляючи власну мову інтерпретації, впізнаваність. Багато його студентів виросли до митців з чітко вираженою кар'єрою: Клаудія Борелла, Скот Чейзелінг, Бен Едолз, Кейті Елліот, Крісті Ріа та ін. А Річард Вайтлі згодом очолив майстерню скла у канберзькій школі.

Клаус Мойє присвятив десять років життя педагогічній роботі в університеті, продовжуючи творчо розвиватись. Але, навіть після завершення викладацької діяльності, він продовжував піклуватися про своїх студентів і співпрацювати з ними. Завдяки його клопотанню багато хто з них мав можливість відвідати курси та резиденції за межами Австралії, зокрема у школі Пілчак і в гутній студії Берлін Глас (Berlin Glas e.V.). Це, у свою чергу, вили- 
лось у міжнародний багаторічний проєкт під назвою «Спільні зусилля: Канберра + Берлін» («Collaborative endeavour: Canberra + Berlin»). Уперше він був представлений на колективній виставці у стінах посольства Австралії в Берліні 2015 р. і свідчить про успішну співпрацю між Канберзькою школою мистецтв і Берлін глас [1]. На виставці можна було ознайомитися з роботами відразу кількох поколінь: від творів К. Мойє та його перших студентів до покоління нової генерації, що недавно завершила навчання у Канберрі та працювала в резиденції в Берліні. Відвідувачі проєкту мали змогу прослідкувати розвиток австралійського мистецтва скла через призму діалогу поколінь. Цей проєкт має своє продовження й зараз, навіть після смерті видатного митця.

Загалом Австралія мала глибокий вплив на К. Мойє, формування його образно-стилістичних рис і зв'язок з матеріалом. Враження від краєвидів і мистецтво аборигенів стало стабільним джерелом натхнення для митця. Однак вони не були прямо відтвореними, запозиченими, а стали рефлексіями його особистих вражень на полотні [8]. Якщо Америка дала К. Мойє відчуття свободи, допомогла подолати умовності, то Австралія допомогла розвинути та встановити індивідуальні естетично-стилістичні характеристики. Його палітра збагатилась, а лінії набули ознак живописного мазка. Його перші твори після приїзду до Австралії свідчать про початок нової хвилі творчості. «Без назви №9» із серії «Нові горизонти» (1984) - 40-сантиметровий квадрат, який перетинають паралельні горизонтальні смуги блакитного, зеленого, жовтого, рожевого кольору, неначе живопис імпресіонізму - створює відчуття вібрації неозорого простору, а округла увігнутість по центру, що контрастує 3 прямими кутами квадрата, сприймається як сонце, що сходить. Окремі мозаїки набули виразно експресивного звучання: «Без назви №10» - збірна композиція з 6-ти квадратів, 60 см кожен, на яких яскраво-оранжеві та червоні промені, що ніби «вириваються» 3 площини, перетікаючи на суміжні квадрати, створюючи колосальний ефект ексцентричної динаміки. У своїх роботах митець намагався досягнути відчуття «матеріальності»- на противагу фантомній прозорості та сліпучому блиску, якого домагалися більшість склярів. Поверхні його творів - шовковисто-матові, іноді фактурні, що дозволяє занурити погляд у товщу скла, оцінити глибину кольору [4, с. 42]. Враховуючи по- 
яву нового матеріалу, К. Мойє продовжував експериментувати. Його репертуар поповнювався новими формами: двовимірними панно, «коробками» та циліндрами.

Циліндри К. Мойє - це ще одне його новаторство. Відчуваючи потребу вийти в тривимірний простір, він спробував поєднати свій термоформаж з гутою. Йому довелося співпрацювати 3 майстрами гутної справи. Перша спроба відбулася на базі школи Пілчак з допомогою Біллі Моріса 1982-го. Надалі К. Мойє почав співпрацювати з Данте Маріоні - видатним американським склодувом, виразним представником студійного руху, вихованцем таких метрів гутної справи, як Ліно Тайліап'єтра, Бенджамін Мур, Річард Маркіз. Маріоні увібрав найкращі здобутки класичних італійських технік, що стали характерною ознакою його творчості. Спільно з К. Мойє вони створили низку колекцій різноманітних ваз і циліндрів із попередньо спеченої мозаїки за допомогою гути. Зокрема, на симпозіумах у Чехії (Нови Бор), у майстерні Булсай (1993, шт. Орегон, США). Перевага цього прийому полягає у тому, що можна досягнути складного візерунку за допомогою термоформажу, який складно втілити лише засобами гути. Цікавим досвідом для К. Мойє стала серія гутних циліндрів на основі його мозаїк під час резиденції на острові Ніїджіма, Японія (1997), жоден з яких, на жаль, не вцілів. Однак його колишні студенти Крісті Ріа та Скот Чейзелінг, перейнявшись досвідом учителя, успішно продовжили експерименти [8, с. 53]. Таким чином, учорашні вихованці К. Мойє стали йому колегами по цеху.

Клаус Мойє активно розвинув творчу діяльність після завершення десятирічної кар'єри у сфері освіти. Цей період був дуже плідний на виставки та нагороди. Одні з найбільш значущих: Нагорода Австралійського творчого товариства (1995); Комісія ім. Ракових, Музей скла у м. Корнінг, США (1999); нагорода «За життєві досягнення» від Міжнародної спілки художнього скла, Нью-Йорк, США (2000); нагорода ім. Лібенського-Брихтової, Школа скла Пілчак, США (2013). Ці нагороди спільноти художнього скла свідчать про колосальний внесок митця у всесвітню спадщину, який важко переоцінити.

Виставкова активність К. Мойє налічує десятки персональних і колективних виставок з дуже широкою географією: Австралія, США, Німеччина, Японія, різні країни Європи. Це були масш- 
табні та камерні експозиції в стінах відомих музеїв і приватних галерей, які можна довго перераховувати, але хочеться звернути увагу на ретроспективну виставку, що стартувала в Сиднеї 2006-го та відбувалася у різних куточках Австралії. Згодом, 2008-го, виставку відкрили в Штатах - у Нью-Йорку та Портланді. Експозиція виставки охопила твори від раннього періоду 1970-х - чаші та тарілки спечені з прутиків легкоплавкого скла - до монументальних панелей, виконаних спеціально для цієї виставки. За словами митця, «це чудова можливість більш виразно прослідкувати, що відбувалось у твоєму розвитку та краще оцінити свої здобутки» [8, с. 52].

Брюс Гюнтер, головний куратор Портландського художнього музею (2000-2014), звернувся до К. Мойє з ідеєю створити щось справді масштабне, що стало $б$ центральним твором його ретроспективи. Так народилися «Портландські панелі: балет геометрії» - чотири масивних скляних полотна (190 х 120 см кожне). Вони стали апогеєм майстерності та вишуканості. Хаотично структуровані композиції пульсують лініями, що перетинаються, створюючи динамічний тривимірний ефект. Найкращим чином тут проявилася здатність автора з чуттям добирати «компоненти» для досягнення найкращих оптичних властивостей матеріалу. Ці приголомшливі мозаїчні панно були створені на базі фабрики Булсай ґлас, що стало підсумком багаторічної дружби К. Мойє та Булсай. Від 2015 р. ця робота перебуває у постійній експозиції Музею скла міста Корнінг, США.

Це не єдина робота К. Мойє у збірці музею. Як згадувалось вище, 1999 р. один із циліндрів із серії «Ніїджіма» був відібраний за програмою комісії ім. Ракових. Окрім того, музей володіє комплексним панно, що складається з дев'яти окремих квадратів, об'єднаних живописними лініями червоного, чорного та жовтого кольорів, очевидно, інспіроване ландшафтом австралійського краю.

Загалом, роботи К. Мойє зберігаються у понад 50-ти публічних колекціях і приватних збірках у Австралії та за ї̈ межами.

Твори К. Мойє - це, передовсім, дослідження кольору. Його скляні полотна мають ознаки живопису з усіма перевагами властивостей скла, які митець належно оцінив за його глибину, прозорість, хроматичну насиченість. Його масивний творчий доробок промовисто ілюструє відданість матеріалу та гармонію 
ремесла з мистецтвом.

Висновки. Клаус Мойє - митець, педагог, інноватор. Незважаючи на свою стриману зовнішність і щирість, уся внутрішня сила та напруга відображається на іноді сповнених драматизму скляних полотнах.

Поки художники міжнародного руху студійного скла зосередили свою увагу на гутному склі, К. Мойє продовжував удосконалюватись у техніці спікання скла, розширивши розуміння скла як медіума технічно та концептуально. Завдяки експериментам митцеві вдалося відродити давню технологію та надати їй нового змісту. Мозаїки К. Мойє набули цілісного звучання, що простежується в експресивному наповненні стриманого подання. К. Мойє запровадив новий підхід до роботи зі склом у персональній студії, що раніше було неможливим. Завдяки співпраці з виробником вітражного скла «Булсай ґлас» (Bullseye glass co.) і появі сумісного за КТР (коефіцієнт термічного розширення) скла, термоформаж став доступною технікою і набув поширення по всьому світу, розповсюджуючи ідеї студійного художнього скла. Клаус Мойє мав значний вплив на студійний рух Австралії через освітній процес, як наслідок, - під його кураторством проявилася плеяда всесвітньо визнаних молодих митців.

Художнє скло К. Мойє ще тривалий час залишатиметься надійним підгрунтям та відправною точкою для всіх тих, кому не байдужі щирість, яскравість і чистота цього бездоганного матеріалу.

1. Anderson N. On Klaus Moje and Collaborative Endeavours: Canberra + Berlin Neues glas - new glass: art Q architecture. 2015. № 4. C. 8-13.

2. Anderson Nola. URL : https://www.smh.com.au/entertainment/art-and-design/ how-klaus-moje-changed-australias-glass-art-20151016-gkb68c.html (дата звернення: 12.04.2019).

3. Brennen A. Interview: Klaus Moje. Glass. 1997. № 68. C. 50-53.

4. Guenther B. ChromaZone. Glass. 2008. № 111 (Summer). P. 40-49.

5. Pilchuck glass school. URL :http://www.pilchuck.com/history (дата звернення: 4.04. 2019).

6. Harvey K. Littleton and the American studio glass movement / Corning muzeum of glass. URL :https:/www.cmog.org/article/harvey-k-littleton-and-americanstudio-glass-movement (дата звернення: 3.04. 2019). 
7. Keith Cummings, Lani McGregor, Daniel Schwoerer \& Geoffrey Wichert. Contemporary Kilnformed Glass: An International Exhibition. Bullsey Glass Co. Portland Oregon, USA. 1992. 103 p.

8. Moje K. Thirty years of exploration in glass. Glass Art Society Journal, 2000. P. 48-53.

9. Nola Anderson. URL : https://sabbiagallery.com/exhibition/momentum/?fbclid=I wAR1NIeRB7Smf48uNISlAmk0So2ayRnpk8gyBaNxIQ9PkEf7quRrhepQTgnU (дата звернення 22.03.2019).

10. Bottari M. Klaus Moje : glass. Fishermans Bend, Vic. : Craftsman House, 2006. 143 p.

11. Whiteley R., Introduction. Glass Art Society Journal, 2000. № 4. P. 46-47.

12. Whiteley R., Jakle A. Biographical notes. Glass Art Society Journal. 2000. № 4. P. 47-48.

13. Бокотей М. А. Дизайн ужиткового скла та пластичні композиції Іржі Шугаєка. Вісник Львівської національної академії мистеитвв. 2013. Вип. 23. С. 262-271.

14. Казакова Л. Мировое художественное стекло XX века. Основные тенденции ведущие мастера. Москва : Пинакотека, 2007. 272 с.

\section{References}

1. Anderson N. (2015). On Klaus Moje and Collaborative Endeavours: Canberra + Berlin. Neues glas - new glass: art $\bigcirc$ architecture, 4. 8-13.

2. Anderson Nola. Retried from ttps:/www.smh.com.au/entertainment/art-and-design/ how-klaus-moje-changed-australias-glass-art-20151016-gkb68c.html.

3. Brennen, A. (1997) Interview: Klaus Moje, Glass, 68, 50-53.

4. Guenther B. (2008). ChromaZone. Glass, 111, 40-49.

5. Pilchuck glass school. Retried from http://www.pilchuck.com/history

6. Harvey K. Littleton and the American studio glass movement / Corning muzeum of glass. Retried from https:/www.cmog.org/article/harvey-k-littleton-and-americanstudio-glass-movement

7. Keith Cummings, Lani McGregor, Daniel Schwoerer \& Geoffrey Wichert (1992). Contemporary Kilnformed Glass: An International Exhibition. Bullsey Glass Co. Portland Oregon, USA.

8. Moje, K. (2000) Thirty years of exploration in glass. Glass Art Society Journal, 48-53.

9. Nola Anderson. Retrived from https://sabbiagallery.com/exhibition/momentum /?fbclid=IwAR1NIeRB7Smf48uNISlAmk0So2ayRnpk8gyBaNxIQ9PkEf7quRr hepQTgnU [In English].

10. Bottari, M. (2006). Klaus Moje : glass. Fishermans Bend, Vic. : Craftsman House.

11. Whiteley, R. (2000). Introduction. Glass Art Society Journal, 4, 46-47.

12. Whiteley, R. \& Jakle, A. (2000). Biographical notes. Glass Art Society Journal, 4, 47-48.

13. Bokotey, M. (2013) Dyzayn uzhytkovoho skla ta plastychni kompozytsiyi Irzhi Shuhayeka. [Design of glassware and plastic compositions by Jiri Shugayek] Visnyk L'vivs'koyi natsional'noyi akademiyi mystetstv, 23, 262-271. [in Ukrainian]. 
14. Kazakova L. (2007) Mirovoye khudozhestvennoye steklo XX veka. Osnovnyye tendentsii vedushchiye mastera. Moskva : Pinakoteka, [in Russian].

\section{ANNOTATION}

Ostap Ivanyshyn. Experiment in the art of Klaus Moje.The paper overviews a lifetime achievement of german native australian artist Klaus Moje in the field of decorative glass art. An article traces the development of his artwork in the late 1900th - early 2000th. Much attention is given to Moje s innovative approach of traditional technique. It is made an attempt to evaluate the implementation of new methods and technics to the educational process. It is analysed a contribution of an artist in the context of the studio glass movement. The paper describes most creative periods and examines appropriate artworks. The results of collaboration between an artist and a manufacturer of coloured glass are revealed. Main articles to the theme is observed. The determination of kilnforming, as an independent medium technique is considered. The results obtained confirm the significant contribution of an outstanding artist, which allows to determine his prominent place in thy world history of art.

Key words: art glass, Klaus Moje, studio glass movement, kilnforming, educational process, innovative approach.

\section{АННОТАЦИЯ}

Остап Иванышин. Эксперимент в творчестве Клауса Мойей. В статье освещены вклад творческой и образовательной деятельности известного австралийского художника немецкого происхождения Клауса Мойе в мировое наследие декоративного искусства в сфере художественного стекла. Раскрыто его инновационный подход к работе с материалом. Исследована роль художника в развитии международного движения студийного стекла. Выяснено последствия совершенствования технологии на перспективы развития техники спекания стекла в студийных условиях и внедрение ее в учебные программы. Проведен краткий обзор основных публикаций и исследований творчества художника и охарактеризованы его творчество на протяжении четырех десятилетий. Выявлено результаты сотрудничества с производителем специализированных материалов. Осуществлен краткий обзор ретроспективной выставки.

Ключевые слова: творчество Клауса Мойе, международное движение студийного стекла, термоформаж, живопись в стекле, реновация. 